\title{
A New On-Line Detecting Apparatus of the Residual Chlorine in Disinfectant for Fresh-Cut Vegetables
}

\author{
Chao $\mathrm{Hu}^{1}$, Shu-qiang $\mathrm{Su}^{2}$, Bao-guo $\mathrm{Li}^{1, *}$, and Meng-fang $\mathrm{Liu}^{1}$ \\ ${ }^{1}$ Institute of Food and Biotechnology, University of Shanghai for Science and Technology, \\ Shanghai 200093, P.R. China \\ lbaoguo@126.com \\ ${ }^{2}$ Shanghai General Cooling Technology Co., Ltd, shanghai 201201
}

\begin{abstract}
With the fast development of modern food and beverage industry, fresh-cut vegetables have wider application than before. During the process of sterilization in fresh-cut vegetables, the concentration of chloric disinfectant is usually so high that the common sensor can't be used directly on the product line. In order to solve this problem, we have invented a new detecting apparatus which could detect high concentration of chloric disinfectant directly. In this paper, the working principle, main monitor indicators, application and technical creations of the on-line apparatus have been discussed, and we also carried on the experimental analysis for its performance. The actual demands in factory could be met when the detecting flux is $2 \mathrm{~L} / \mathrm{min}$, the dilution ratio is 15 and input amount of the disinfectant is $200 \mathrm{ml}$ per time, the max of the detecting deviation achieves $\pm 4.8 \mathrm{ppm}(\mathrm{mg} / \mathrm{L})$. The main detecting range of residual chlorine is $0 \sim 300 \mathrm{ppm}$.
\end{abstract}

Keywords: Fresh-cut Vegetable; Residual Chlorine; Dilution Ratio; Sensor.

\section{Introduction}

China is a large agricultural nation. Vegetables are rich in resources and varieties with high quality and low price. In recent years, the volume of the world trade on vegetables have increased significantly. In China, the loss ratio after vegetables' picking reaches as high as 40\% 50\%, the same on the commodity surpasses $30 \%$, resulting in a huge economic loss [1]. Fresh-cut vegetables are also called semiprocessed vegetables, cooking vegetables, minimally processed vegetables, which are kind of instant vegetable products based on the fresh vegetable as raw material. They are processed by cleaning, peeling, cutting, trimming and packing, then entering the supermarket after the refrigeration and transportation for sale. They are fresh in quality, edible conveniently, nutritious, clean etc [2]. Moreover, they can extend the shelf life effectively and reduce loss markedly.

Through the vegetable's cutting process, the internal tissue is vulnerable to damage because of the microbial contamination. So it usually uses chloric disinfectant for

*Corresponding author, Tel: +86-21-55271117, Email:lbaoguo@126.com 
cleaning and sterilizing process to extend their shelf life and keep the vegetables safety [3].

At present, commonly used as chloric disinfectant is chlorine molecule, hypochlorous acid or calcium hypochlorite. Chloric disinfectant hydrolysis in water to form hypochlorous acid(As shown in formula(1)(2)(3)), and hypochlorous acid further decompose to form intense-oxidation oxygen [O], which has so highly oxidizing capability towards bacteria, viruse and pathogenic micro-organisms, it also can cause the protein denaturation.

$$
\begin{aligned}
\mathrm{Cl}_{2}+\mathrm{H}_{2} \mathrm{O} & \rightarrow \mathrm{HClO}+\mathrm{HCl} \\
\mathrm{NaClO}+\mathrm{H}_{2} \mathrm{O} & \rightarrow \mathrm{HClO}+\mathrm{NaOH} \\
\mathrm{Ca}(\mathrm{ClO})_{2}+2 \mathrm{H}_{2} \mathrm{O} & \rightarrow 2 \mathrm{HClO}+\mathrm{Ca}(\mathrm{OH})_{2}
\end{aligned}
$$

The hypochlorous acid will decompose the hydrogen ion and the hypochlorite ion in water(4):

$$
\mathrm{HClO} \leftrightharpoons \mathrm{H}^{+}+\mathrm{ClO}^{-}
$$

The bactericidal effect of disinfectant has been proportioned with the concentration of hypochlorous acid. The bactericidal effect of $\mathrm{HClO}$ in disinfectant is about a hundred times stronger than $\mathrm{ClO}^{-}, \mathrm{HClO}$ 's ratio increases along with the $\mathrm{pH}$ value reducing. Therefore, in the disinfection we may judge its bactericidal effect correctly through the content of hypochlorous acid. Pirvani abroad carried lettuce for sterilization experiment and he found that there existed bactericidal effect when the actual concentration of residual chlorine is $50 \sim 150 \mathrm{mg} / \mathrm{L}^{[4]}$.Domestically, Professor Lu Zhaoxin in Nanjing Agricultural University studied that sodium hypochlorite solution kill the E. coli most effective when the actual concentration of residual chlorine is $125 \mathrm{mg} / \mathrm{L}$ [5].

Vegetable processing enterprises use chloric disinfectant whose actual concentration of residual chlorine is mainly $75 \sim 200 \mathrm{mg} / \mathrm{L}$ in the production of the fresh-cut vegetables. Whereas in the current market, detector on chloric disinfectant focus on $0 \sim 5 \mathrm{mg} / \mathrm{L}$, so it can not be directly used on the product line of fresh-cut vegetables for detecting high concentration of chloric disinfectant [6]. In this article, it uses the method of dilution ratio, developing on-line detecting apparatus of the high concentration of residual chlorine to solve the problem above.

\section{Working Principle}

\subsection{Principle of Residual Chlorine Sensor}

The residual chlorine sensor used in apparatus is a galvanometer sensor based on the electrochemistry. It consists of the cathode, anode and electrolyte, the cathode is covered by a layer of membrane with gas permeability. Residual chlorine in measured fluid spread to the cathode through the membrane, then the cathode and anode polarize between appropriate voltage. Residual chlorine is reducted in the cathode when producing electrical current and thus measure the concentration of residual chlorine. The current is directly proportional with the chemical reaction in the sensor of residual chlorine from solution. 


\subsection{Principle of the On-Line Detecting Apparatus}

In view of common residual chlorine sensor, whose measuring scope is finite from $0 \sim 5,0 \sim 10$ or $0 \sim 20 \mathrm{ppm}$. We choose dilution in certain ration as the method of the detecting apparatus. As shown in Figure 1, the diluent water and a certain amount of disinfectant mixes in the A. B place controls the best examination current capacity scope by the transit discharge controlling element, then completes the examination in $\mathrm{C}$ place, finally the density value which will be examined through the $\mathrm{D}$ place where returns the concentration to original state and demonstrate the actual disinfection fluid density. Simultaneously, using the programmed logic controller guarantee that the disinfection in product line satisfies the sterilize request all the while.

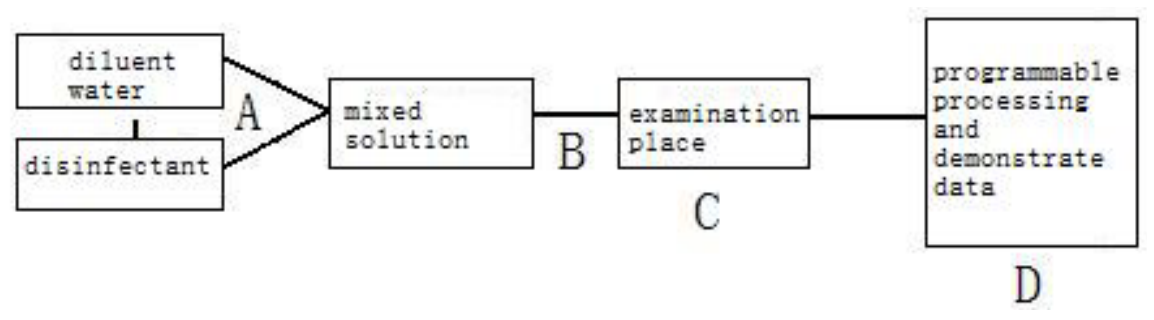

Fig. 1. operative principle of on-line detecting apparatus

\section{The Main Monitoring Factors}

\subsection{Residual Chlorine}

Residual chlorine is the total chlorine's content after the reaction with the deoxidizer when the disinfectant adding into the water to be possessed, including active chlorine, hypochlorous acid and organic chloride rather than chlorine ions. The bactericidal effectiveness of chloric disinfectant depends on the concentration of hypochlorous acid from residual chlorine. In the vegetable process, the concentration of hypochlorous acid is not only the key parameter measuring whether it has enough bactericidal effect, but also an important indicator of detection at the end of the cleaning the vegetables for wiping off the residual chlorine. The purpose of monitoring is to ensure the concentration of hypochlorous acid is in certain extent that have effective sterilization. Generally the concentration of hypochlorous acid is too high may increase the residual chlorine's content and lead to waste of resources; or too low would reduce the bactericidal effect.

\section{$3.2 \mathrm{pH}$}

According to $\mathrm{pH}$ value in different water, the possible exist form of residual chlorine is: chlorine molecule dissolved in water $\left(\mathrm{Cl}_{2}\right)$, hypochlorous acid $(\mathrm{HClO})$ or Hypochlorite ion (ClO-). $\mathrm{Cl}_{2}$ and $\mathrm{HClO}$ is in equilibrium in a certain temperature $\left(\mathrm{K} 25^{\circ} \mathrm{C}=4 \times 10^{-4}\right)$.In the same way, $\mathrm{HClO}$ and $\mathrm{ClO}$ - is also in equilibrium in a certain temperature $\left(\mathrm{K} 25^{\circ} \mathrm{C}=\right.$ 2.9x10-8).

Figure 2 shows that in a typical drinking water, the $\mathrm{pH}$ value approximately equal to 7.5. Under this condition, both $\mathrm{HClO}$ and $\mathrm{ClO}$ - exist. The bactericidal effect of 


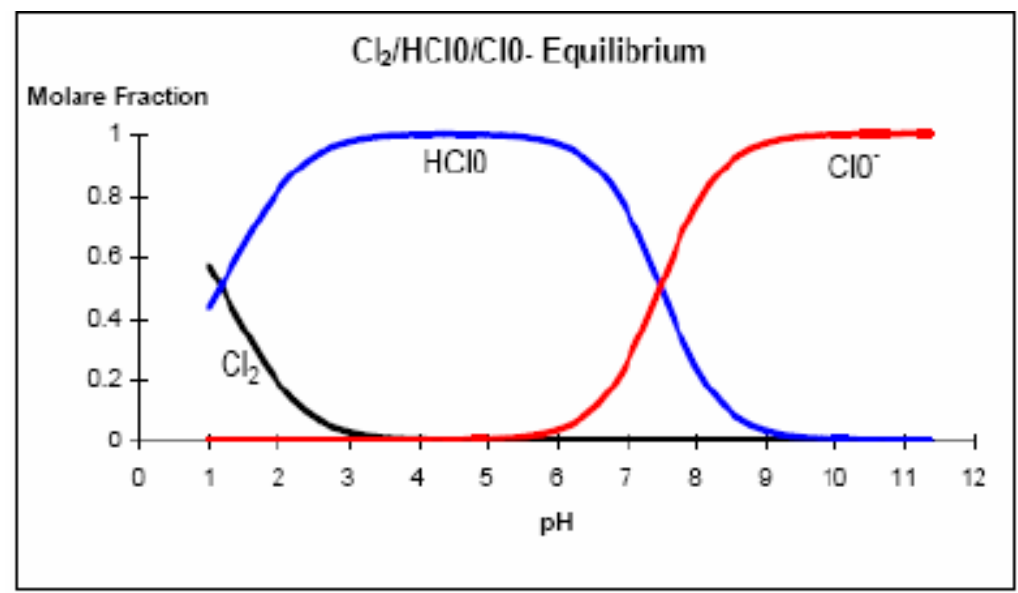

Fig. 2. The equilibrium carve between $\mathrm{Cl} 2, \mathrm{HClO}$ and $\mathrm{ClO}$ - in different $\mathrm{pH}$

$\mathrm{HClO}$ in disinfectant is about a hundred times stronger than $\mathrm{ClO}-$, so the effect of chloric disinfectant depends on its $\mathrm{pH}$ value.

\subsection{Temperature}

Effect of temperature on the residual chlorine measurement is divided into two parts: first, because the dynamic balance between $\mathrm{HClO} / \mathrm{ClO}$ - depends on the temperature; Second, because the principle of sensor is based upon the electrochemical reaction, while the temperature will affect the measurement of hypochlorous acid by bringing fluctuations in electrochemical reaction. Therefore, accurate detection of concentration of chloric disinfectant needs monitoring temperature.

\section{Results and Discussion}

\subsection{The Effect on the Apparatus by the Flux of Disinfectant}

According to the principle of current sensor, detecting flux is very important for the accurate detection. As can be seen from Figure 3, when the detecting flux is between $20 \sim 80 \mathrm{~L} / \mathrm{h}$, the concentration of $\mathrm{HClO}$ detected by the sensor is smaller than the titration value by iodometry. A possible reason is the speed that the testing disinfectant washout the probe head is too slow, causing the $\mathrm{HClO}$ in the testing fluid do not penetrate into tectoria membrane of the probe head completely. When the flux is greater than $120 \mathrm{~L} / \mathrm{h}$, the residual value of detection of the sensor is greater than the titration value by iodometry, this possible reason is the velocity of testing disinfectant in the pipeline has speeded up and $\mathrm{HClO}$ amount enters tectoria membrana has increased in per unit time which heighten effective degree to washout electrode. At the meantime, the frequency of shifting electric charge speed up, thus causing the correspondence concentration value is high. When the detecting flux is $80 \sim 120 \mathrm{~L} / \mathrm{h}$, both test results are basic consistent. So the design prototype selects $100 \mathrm{~L} / \mathrm{h}$ as the detecting flux. 


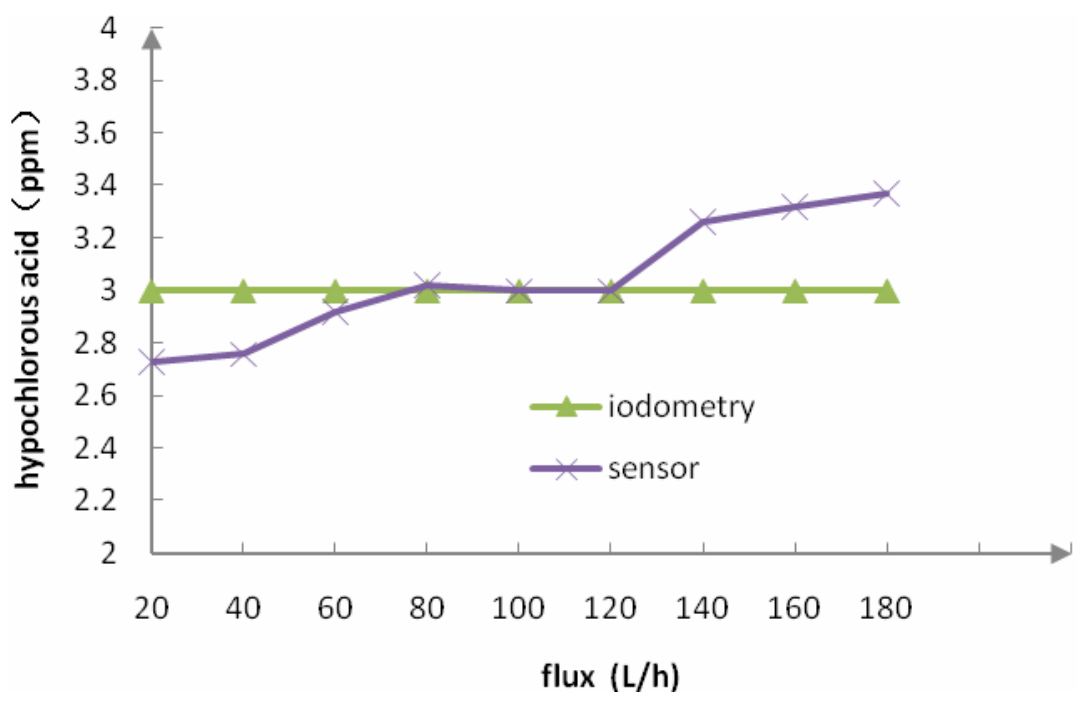

Fig. 3. Effect of detecting flux on the measurement of $\mathrm{HClO}$

\subsection{The Effect on the Apparatus by $\mathrm{pH}$ of Disinfectant}

The bactericidal effect of disinfectant has been proportioned with the concentration of $\mathrm{HClO}$, and $\mathrm{HClO}$ 's ratio to $\mathrm{ClO}$ - in the water increases along with the $\mathrm{pH}$ reducing. Figure $4 \mathrm{a}, 4 \mathrm{~b}$ showed that when the $\mathrm{pH}=7.5\left(25^{\circ} \mathrm{C}\right)$, only $50 \%$ of residual chlorine turned to $\mathrm{HClO}$; but at $\mathrm{pH}=6.5$, there was about $85 \%$ of $\mathrm{HClO}$; at $\mathrm{pH}=5.5$, the residual chlorine at the form of $100 \% \mathrm{HClO}$. In Figure 4a the original concentration of residual chlorine is $5 \mathrm{ppm}$, Figure $4 \mathrm{~b}$ is $10 \mathrm{ppm}$. The changes are basically in accord with the trend curve of $\mathrm{HClO}$ in Figure 2. Thus, we can draw that the key point in the preparation of vegetable disinfectant is controlling its $\mathrm{pH}$ value, as far as possible make it in 6 below for maximum amount of $\mathrm{HClO}$.

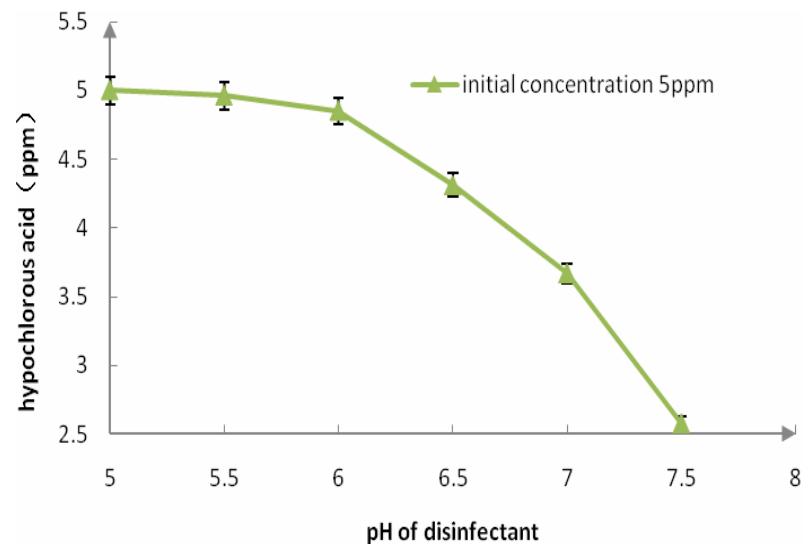

Fig. 4. a,b: Effect of $\mathrm{pH}$ of disinfectant on the measurement of $\mathrm{HClO}$ 


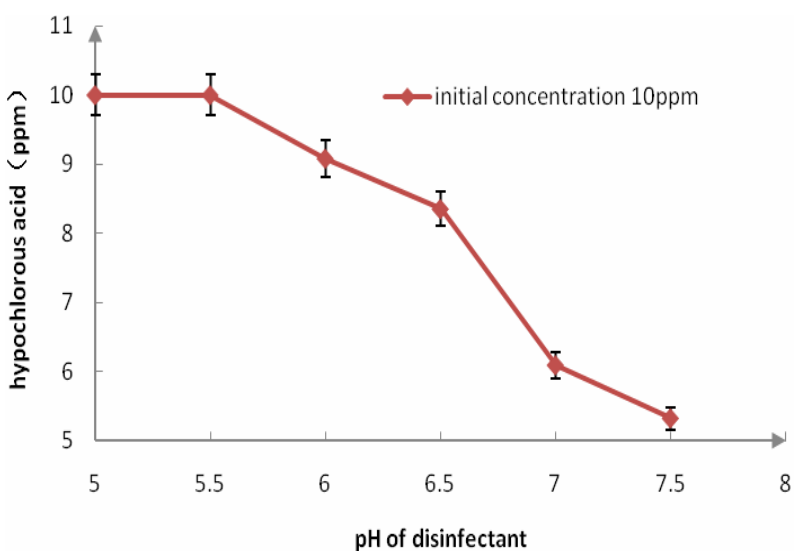

Fig. 4. (Continued)

\subsection{The Effect on the Apparatus by Response Time}

Known from Figure 5, with the response time extending, the apparatus displayed a gradual increase in concentration of $\mathrm{HClO}$. When the time range was $5 \mathrm{~s}$ to $30 \mathrm{~s}$, the concentration of $\mathrm{HClO}$ increased significantly, then the data on the screen came to basic balance after 30s. This is because the residual chlorine sensor needs certain time for accomplishing the electrochemical reaction. $\mathrm{HClO}$ was detected and consumed from the testing disinfectant when it entered tectoria membrana of the sensor, and non-stop supply of disinfectant to achieve a balance. From the Figure 5, the initial concentration of $\mathrm{HClO}$ is $5,10 \mathrm{ppm}$ respectively, and for the on-line detecting apparatus the best response time is $30 \sim 40 \mathrm{~s}$.

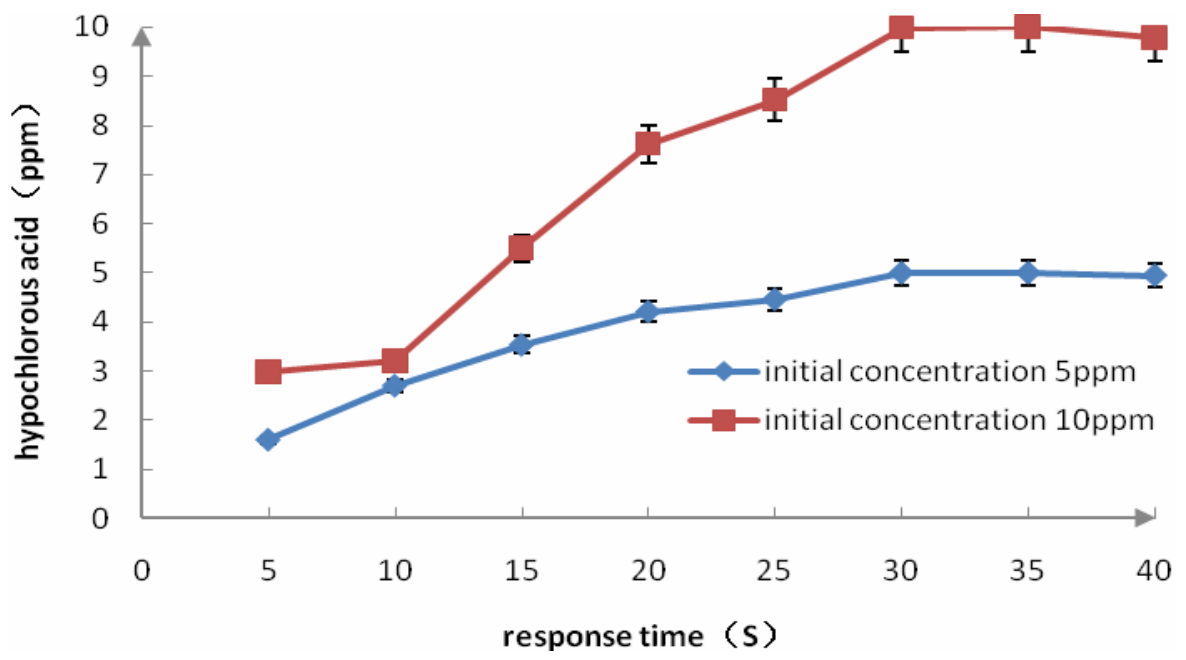

Fig. 5. Effect of response time on the measurement of $\mathrm{HClO}$ 


\subsection{The Test Experiment of Apparatus in Factory}

Normally, the vegetable product line will prepare $150 \mathrm{ppm}$ of sodium hypochlorite as disinfectant. We took some sample for testing, the results showed in Figure 6: the pink carve describing the testing concentration of $\mathrm{HClO}$ by the apparatus, the result's maximum deviation from the actual data is $\pm 4.8 \mathrm{ppm}$. Sodium hypochlorite's own nature has decided the examination deviation. Because, the sodium hypochlorite very easy to decompose in the illumination and under the washout condition. Besides, in the clean process, in order to separate the microorganism from the vegetables' surface as soon as possible, air blower used to produce the air bubble which has the function to accelerate the separation. Involuntarily, the air bubble also intensifies the decomposition of the sodium hypochlorite. In addition, operational site's illumination has also created the condition for decomposition. Therefore, the actual concentration of $\mathrm{HClO}$ has the drop slightly. We also learned from the blue line which representing the response time of the on-line detecting apparatus in Figure 6, the average reaction time is $37 \mathrm{~s}$, which satisfies the actual working request.

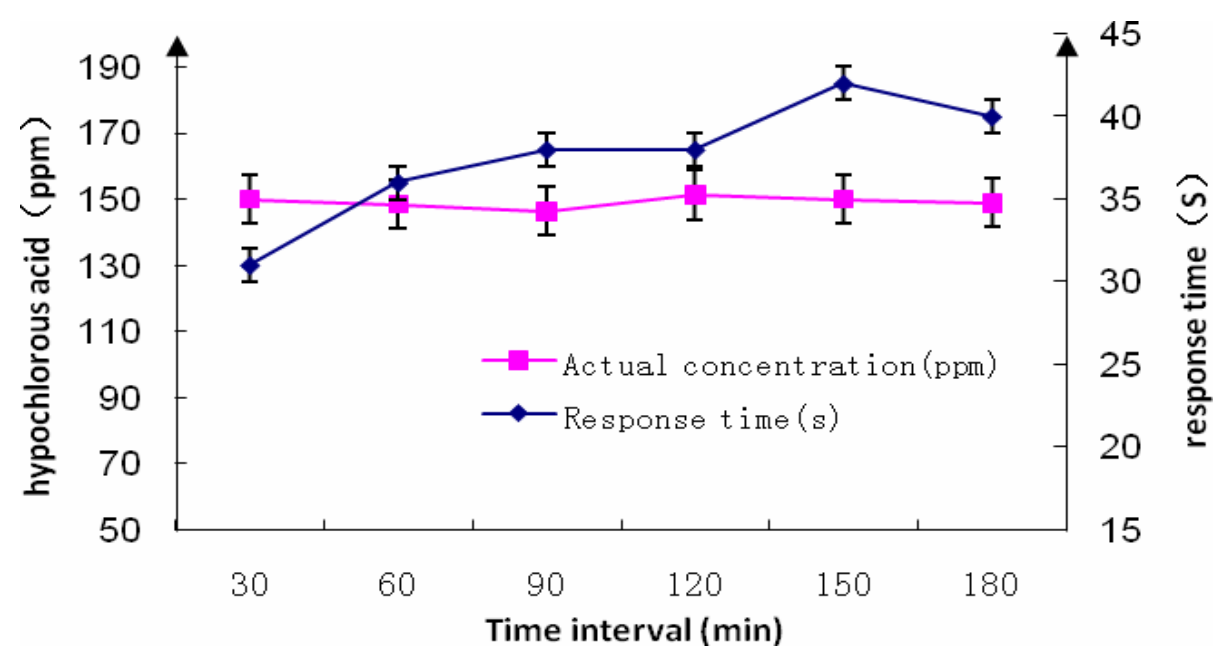

Fig. 6. Field-testing of the apparatus and its response time

\section{Conclusion}

The on-line detecting apparatus of residual chlorine in disinfectant for fresh-cut vegetables adopts the simple principle of proportion dilution, acquiring residual chlorine data by galvanometer sensor, and then processing the data through the microprocessor to realize the intelligent of machine. The results of measurement are basically consistent with the GB method. Compared with foreign devices, the relative deviation of measurement of domestic detector is higher. While the relative deviation of this detector is lower than the domestic similar products, and much closer to foreign analyzer in results. The main performance index also reached advanced level 
contrast with the overseas similar instruments. Furthermore its low price will reduce the cost of customers. The apparatus is controlled by programmable logic controller(PLC), so it can meet the requirements of the on-line measurement of disinfectant in food industry because of its convenient operating, good stability and high accuracy.

\section{References}

Qinsheng, L.: Our country vegetables processing and circulation present situation and trend of development. Machinery For Cereals,oil and Food Processing (3), 1-4 (2000)

http: / /www. fresh-cuts.org (International association of fresh-cuts product)

Xuejie, Z.: Our country vegetables processing industry present situation and faced with WTO opportunity and challenge. Science and Technology of Food Indusry (1), 82-85 (2001)

Pirovani, M., Piagentini, A., Güemes, D., et al.: Reduction of chlorine concentration and microbial load during washing-disinfection of shredded lettuce. Int. J. Food Sci. \& Technol. (39), 341-347 (2004)

Likui, Z., Zhaoxin, L.: Study on predictive model for total coliform group reduction on freshcut lettuce treated with NaClO. Food Science (7), 67-71 (2004)

Sapers, G.M.: Efficacy of Washing and Sanitizing Methods for Disinfection of Fresh Fruit and Vegetable Products. J. Food Technol. (39), 305-311 (2001)

Shihao, M., Bo, L.: Hospital sewage disposal. Chemical industry publishing house, Beijing (2000)

EMERSON. Chlorine measurement by amperometric sensor. EMERSON Process Management Company

Shimano, T.: New design of geodesic lenses. In: MOC/GRIN 1989, Tokyo, pp. 130-135 (1989) 